TITLE:

Higher expression of EphA2 and ephrin-A1 is related to favorable clinicopathological features in pathological stage I non-small cell lung carcinoma(Abstract_要旨)

\title{
$\operatorname{AUTHOR}(S)$ :
}

\section{Ishikawa, Masashi}

\section{CITATION:}

Ishikawa, Masashi. Higher expression of EphA2 and ephrin-A1 is related to favorable clinicopathological features in pathological stage I non-small cell lung carcinoma. 京都大学, 2013, 博士(医学)

ISSUE DATE:

2013-03-25

URL:

http://hdl.handle.net/2433/174772

RIGHT: 


\begin{tabular}{|l|l|c|c|}
\hline 京都大学 & 博士 $($ 医 学) & 氏 名 & 石 川 将 史 \\
\hline & $\begin{array}{l}\text { Higher expression of EphA2 and ephrin-A1 is related to favorable clinicopathological } \\
\text { 論文題目 }\end{array}$ & $\begin{array}{l}\text { features in pathological stage I non-small cell lung carcinoma } \\
\text { (病理病期 I 期の非小細胞肺癌における EphA2 と ephrin-A1 の高発現は良好な } \\
\text { 臨床病理学的特徴と関連する) }\end{array}$ \\
\hline (論文内容の要旨 $)$
\end{tabular}

非小細胞肺癌は予後不良の疾患であり、治療成績の改善には完全切除例を増やす ととともに今後の有効な薬物療法の開発が必要不可欠である。近年、癌化に関わ る分子やシグナルを特異的に阻害寸る分子標的阻害薬の開発が進んでおり、現在 その標的として最たるものが受容体型チロシンキナーゼである。

受容体型チロシンキナーゼの中でも Eph ファミリーは最大のグループを形成する もので、特に EphA2 は各種の癌での高発現や癌化シグナルへの関与が確認されて いる。ephrin-A1 は細胞膜上に発現する EphA2 のリガンドで、EphA2 と合わせ て癌の治療ターゲットとして期待されている。しかし非小細胞肺癌におけるこれ らの分子の発現や癌化に関わるメカニズムは未だ不明な点が多く、現時点では今 後の十分な治療効果を保障するまでには到っていない。

当論文では、当施設で治療を行った病理病期 I 期の完全切除後の非小細胞肺癌を 対象として、EphA2 と ephrin-A1 の遺伝子及びタンパクの発現を定量的 PCR 法 及び免疫組織化学染色を用いて測定し、低発現群・高発現群の 2 群間の比較によ り臨床病理学的特徽及び生存率を分析した。

EphA2 及び ephrin-A1 の遺伝子高発現群はいずれも女性・非喫煙者・腺癌・高分 化・病理病期 IA $\cdot E G F R$ 遺伝子変異などの一般に予後良好とされる臨床病理学的 因子を多く含んでおり、また生存率の比較では全生存率・無再発生存率ともに EphA2 高発現群が低発現群に比べて有意に高かった。タンパク発現の比較でも患 者分布に同様の傾向がみられ、統計学的有意差は得られなかったものの、生存率 分析で遺伝子発現の結果に矛盾しない傾向が見られた。これらは他癌種も含めた 従来の報告では見られなかった傾向である。近年 EphA2 はリガンド（ephrin-A1） 依存性に働く時はむしろ腫瘍抑制的に働くことが知られており、今回の結果によ り、早期の非小細胞肺癌では EphA2 がリガンド依存的・腫瘍抑制的に働いている 可能性が示された。EphA2/ephrin-A1 システムを非小細胞肺癌の治療ターゲット と寸る際には、これらの特性を更に明らかにし、踏まえた上で腫瘍進行度に応じ た戦略を立てる必要があると考えられた。
（論文審査の結果の要旨）

EphA2 及び ephrin-A1 は近年癌との関わりが多数報告され、今後有望なバイオ マーカー・治療標的となり得る受容体型チロシンキナーゼ及びそのリガンドで あるが、肺癌、特に病理病期 I 期の非小細胞肺癌におけるこれらの分子の働き は未だに明確ではない。

本研究では、完全切除を受け、病理病期 I 期と診断された前治療歴のない非 小細胞肺癌の検体を用いて、腫瘍組織における EphA2/ephrin-A1 の遺伝子・タ ンパク発現と臨床病理学的特徵及び生命予後について詳細な検討が加えられ た。その結果、EphA2 及び ephrin-A1 の遺伝子高発現群は共通して予後良好因 子を多く含み、EphA2 遺伝子高発現群は低発現群に比べて生存曲線において子 後良好であった。タンパク発現に関しては生存曲線での有意差は得られなかっ たが、EphA2/ephrin-A1 の高発現群が予後良好との傾向に矛盾しない結果であ った。

この結果は、最近報告されている、EphA2/ephrin-A1 が癌化の諸段階で果たす 多様な役割の一つを反映しているものと考えられ、今後これらの分子を治療標 的とする際には患者背景を考慮する必要があることを示唆するものであった。

以上の研究は非小細胞肺癌における EphA2/ephrin-A1 システムの機能の解明に貢献 し、これらを利用した肺癌の新規バイオマーカーや分子標的治療の開発に寄与寸るとこ ろが多い。

したがって、本論文は博士（医学 ）の学位論文として価值あるものと認める。

なお、本学位授与申請者は、平成 24 年 12 月 27 日実施の論文内容とそれに関連し た試問を受け、合格と認められたものである。 